\title{
GEOGRAPHY SKILLS DOMAIN TAXONOMY
}

\author{
Fahrudi Ahwan Ikhsan ${ }^{1}$, Fahmi Arif Kurnianto ${ }^{2}$, Bejo Apriyanto ${ }^{3}$, \\ Elan Artono Nurdin ${ }^{4}$ \\ ${ }^{1,2,3,4}$ Department of Geography Education, University of Jember, Indonesia \\ Ahwan.fkip@unej.ac.id
}

DOI: $10.19184 /$ geosi.v2i1.7525

Article History: Received Date $19^{\text {th }}$ February 2018, Received Revised $25^{\text {th }}$ March 2018, Accepted Date $25^{\text {th }}$ April 2018, Published Date $30^{\text {th }}$ April 2018

\begin{abstract}
This study aims to explain the geography student skills domain. The focus of this research is the domain of geography skills possessed by students. The research method with the a qualitative approach. Subjects were students of Jember University geography education consisting of 2 men and 2 women with indicators of academic ability value of the national geography exam results. Data collection techniques by observation and interview. Data were analyzed using the processing unit, categorization and interpretation of data. The findings show that the skills of geography for prospective teachers of geography and geographers to be possessed composed as follows: 1st level thinking skills geography (space, phenomena, location and place, region, environment, coordinate, and humans), level 2 skills of analysis geography (scale, distribution, patterns of interaction, interrelation, connectivity, corologi, descriptions, and agglomeration), and level 3 skills of geographic applications (mapping/cartography, remote sensing, geographic information systems, surveying and mapping of the area, and Global Position systems (GPS)). This level difference is used to distinguish the use of knowledge and application of the science of geography.
\end{abstract}

Keywords: Students of geography education, geography Skills

\section{INTRODUCTION}

Geographic information technology development is needed in the country as a spatial construct. An understanding of the geographical conditions for geographers already beginning to be felt necessary in the geostrategy of the Indonesian region. The potential nice area includes land, water, and the air is a challenge for educators in imparting knowledge to the students geography. The role of teachers of geography and geographers can give the perception in building geographic thought. The basic understanding is needed in the face of the digital era in the industrial revolution 4.0. National Research Council (2005) stressed the importance of spatial thinking in the knowledge and workplace. This condition is in 
accordance with the current situation of Indonesia which entered the era of demographic bonus, so the essence of geography necessary to build the concept in theory and application.

Geography knowledge and skills critical to building knowledge of geography Indonesia. The role of geography education is not only the delivery of knowledge alone, but the potential of Indonesian territory is becoming more important. All residents living in the area of Indonesia shall have the thinking skills of geography. Maryani (2009) explained that geography is important to learn because it has four reasons that the reason for existence, ethics, intellectual and practical reasons. All the reasons that become elements in building understanding think geography.

Learners and students need to be given an understanding of geography begin thinking base up to the application. The problems that arise about geography skills as a whole is not yet understood. Kemp (2008) states the understanding of space (spatial literacy) are less appreciated and be taught to students. Impact assessment of spatial understanding into the realm of geography difficult to apply because the difference between the basic concepts and abstract geography teachers and geographers. Understanding of society in general educator geography and geographers to environmental conditions (local spatial knowledge) have not developed well, (McCall, 2008). Levinson (2003) emphasizes that the human brain is equipped with different structures in processing spatial information and spatial thinking abilities based on the neurological system. Therefore we need a basic element in the spatial function in the study of geography as a domain taxonomy think geography.

\section{METHODS}

This research method using a qualitative approach. Moeleong (2013) states that qualitative research is an attempt to build a view studied in detail. These research subjects are students of Jember University geography education consisting of 2 male and 2 female based on academic ability value of the national geography exam results. Data collection techniques by observation and interview. Data were analyzed using the processing unit, categorization and interpretation of data.

\section{RESULTS AND DISCUSSION}

1.Results

Understanding the concept of geography students can be assessed using geographic skills. Forms geography skills include thinking skills such as geography, geography analytical skills and application skills of geography. These three aspects of it as the domain in 
building think geography for prospective teachers of geography and geographers. Concepts think geography is supported by spatial skills as part of the domain of thought geography.

The subject of research, the informant in this study with the indicator (1) Comparing the geography student thinking ability of men and women; and (2) The results of the national exam subjects geography highs and lows as an indicator in determining the subject. Both indicators are used as a basis for data collection interview to the subject of research. The results of field studies through observation and interviews to Jember University geography education students as research subjects can be seen in Table 1:

Table 1. Geography Skills Student Interview Results in Geography Education Jember University

\begin{tabular}{|c|c|c|c|}
\hline \multirow[b]{2}{*}{$\begin{array}{c}\text { Research } \\
\text { Subject Name }\end{array}$} & \multicolumn{3}{|c|}{ Indicators Skills } \\
\hline & $\begin{array}{c}\text { Thinking } \\
\text { Geography }\end{array}$ & $\begin{array}{c}\text { Analysis } \\
\text { Geography }\end{array}$ & $\begin{array}{l}\text { Application } \\
\text { Geography }\end{array}$ \\
\hline EviaAritasari & $\begin{array}{l}\text { 1. Phenomena } \\
\text { 2. Space } \\
\text { 3. Geosphere } \\
\text { 4. Location } \\
\text { 5. Region } \\
\text { 6. Environment } \\
\text { 7. Human }\end{array}$ & $\begin{array}{l}\text { 1. Scale } \\
\text { 2. Phenomena of } \\
\text { nature and human } \\
\text { 3. Corologi } \\
\text { 4. Connectivity } \\
\text { 5. Interrelation } \\
\text { 6. Affordability } \\
\text { 7. Agglomeration }\end{array}$ & $\begin{array}{l}\text { 1. Map } \\
\text { 2. Surveying and mapping } \\
\text { 3. Remote Sensing } \\
\text { 4. Geographic } \\
\text { Information System } \\
\text { 5. Global Position System } \\
\text { (GPS) }\end{array}$ \\
\hline Eva Kurniasari & $\begin{array}{l}\text { 1. Object } \\
\text { 2. Map } \\
\text { 3. Location } \\
\text { 4. Place } \\
\text { 5. Environmental } \\
\text { 6. County } \\
\text { 7. Distance } \\
\text { 8. Geosphere }\end{array}$ & $\begin{array}{l}\text { 1. Scale } \\
\text { 2. Differentiation } \\
\text { area } \\
\text { 3. Connectivity } \\
\text { 4. Interrelation } \\
\text { 5. Affordability } \\
\text { 6. Land suitability }\end{array}$ & $\begin{array}{l}\text { 1. Map and Mapping } \\
\text { 2. Regional Development } \\
\text { 3. Remote Sensing } \\
\text { 4. Geographical } \\
\text { Information System } \\
\text { 5. Global Position System } \\
\text { (GPS) }\end{array}$ \\
\hline $\begin{array}{l}\text { Ahmad } \\
\text { Kurniawan } \\
\text { Dwi }\end{array}$ & $\begin{array}{l}\text { 1. Location } \\
\text { 2. Soordinates } \\
\text { 3. Place } \\
\text { 4. Regional } \\
\text { 5. Environment } \\
\text { 6. Space } \\
\text { 7. Phenomena } \\
\text { 8. Human }\end{array}$ & $\begin{array}{l}\text { 1. Distribution } \\
\text { 2. Patterns } \\
\text { 3. Agglomeration } \\
\text { 4. Interaction } \\
\text { 5. Distance } \\
\text { 6. Connectivity } \\
\text { 7. Distribution } \\
\text { 8. Description } \\
\text { 9. Corologi }\end{array}$ & $\begin{array}{l}\text { 1. Map and mapping } \\
\text { 2. Regional Development } \\
\text { 3. Environmental capacity } \\
\text { 4. Remote Sensing } \\
\text { 5. Geographic } \\
\text { Information System } \\
\text { 6. Surveying } \\
\text { 7. Global Position System } \\
\text { (GPS) }\end{array}$ \\
\hline $\begin{array}{l}\text { Dimas Abdur } \\
\text { Rozaq }\end{array}$ & $\begin{array}{l}\text { 1. Location } \\
\text { 2. Place }\end{array}$ & $\begin{array}{l}\text { 1. Pattern } \\
\text { 2. Agglomeration }\end{array}$ & $\begin{array}{ll}\text { 1. } & \text { Cartography } \\
\text { 2. Environmental }\end{array}$ \\
\hline
\end{tabular}



3. Human
3. Value for
3. Remote Sensing
4. Phenomena
4. Corologi
5. Space
5. Description
4. Geographic
6. Spatial
6. Distribution
Information System
7. Connectivity
5. Survey area and region
6. GPS

Source: Data from the study in 2017

Geography skills provide an overview of the object space of study. The forms of geographic skills provide a picture of the ability to think space for prospective geographers. The data shows the subject can distinguish the essence of the domain of geography skills both in the realm of thinking, analysis, and application.

\section{Discussions}

Skills geography is needed in the study of geography. Candidates require geographers or geography skills in expressing the phenomena of geography in the field. The phenomena that is real in the field need further study, given the geography is also associated with the occurrence of daily life of every human being. Geography skills built with three concepts of the study include: knowledge, analysis, and application. The concept it will help every individual both geographers and prospective geographers in understanding the science of geography to study the location and region. Blij and Muller (1993) description geography as an academic discipline that deals with the explanation of physical and human characteristics on the surface of the earth with an emphasis on a particular place or location. Solem, et.al (2008) The competency model built from the alumni survey data illustrates how professional geographers perceive skill areas as being conceptually related: There was clear discrimination of skills related to physical geography, human geography, and geographic information science and technology. Although the factors represent distinct assemblages of geographic and general skills from the perspective of a sample of professional geographers, the nature of work in pro-fessional geography can involve simultaneous application of many types of skills.

Geography skills need to be supported spatial thinking skills. Study of geography more on space and territories and the people in it. All it into an object of study of geography. Hagget (2001), geography is an integrative dicipline that brings together the physical and human dimensions of the world in the study of people, place, and environment. Herbert and Matthews (2001), geography is the study of the surface of the earth. It involves the phenomena and processes of the earth's natural and human environments and landscapes at 
local to global scales. Higgitt (1996) clasified skills that fieldworks might target into four broad groups: (1) Intellectual (to develop the student's understanding of geography);

Personal (emphasising the importance of vocational and transferable skills); (3) Technical (competence at research methods, using equipment, etc), and (4) Inter alia skills (skill acquired by virtue of being in the field).

Geography skills required the first time the work that geography. Domain taxonomy geography skills need to be built properly so that no one in the study of geography. The following table 2 domain taxonomy needed in the skills of geography:

Table 2 Taxonomy Level Skills Geography

\begin{tabular}{|c|c|c|}
\hline \multicolumn{3}{|c|}{ Skills Geography } \\
\hline $\begin{array}{c}\text { Level 1 } \\
\text { Thinking Skills } \\
\text { Geography }\end{array}$ & $\begin{array}{c}\text { Level } 2 \\
\text { Skills Analysis of } \\
\text { Geography }\end{array}$ & $\begin{array}{c}\text { Level 3 } \\
\text { Skills Application } \\
\text { Geography }\end{array}$ \\
\hline 1. Space & 1. Scale & 1. Mapping/cartography \\
\hline 2. Phenomena & 2. Distribution & 2. Remote Sensing \\
\hline 3. Location and Place & 3. Pattern & 3. Geographic Information \\
\hline 4. Region & 4. Interaction & Systems \\
\hline 5. Environment & 5. Interrelation & 4. Survey and mapping \\
\hline 6. Coordinate & 6. Connectivity & 5. Global Positioning \\
\hline 7. Human & 7. Corologi & Systems (GPS) \\
\hline & 8. Description & \\
\hline & 9. Agglomeration & \\
\hline
\end{tabular}

Geography skills with three levels above has a different domain. More knowledgeoriented thinking and analytical skills of geography, while the application is a combination of knowledge and geographic information technologies. New knowledge can evolve with their geography skills. Level geography skills needed to distinguish between knowledge and application competence of studying geography. These findings confirmed the results Koutsopoulos (2011), proposes an epistemological change had taken place in geographic diciplines, the which is developing into a new scienctific. Kerski (2008a) comments spatial thinking that helps us make sense of spatial patterns, linkages, and relationships. Lee and Bednarz (2009 and 2012) restate that spatial thinking is linked to spatial visualization in order to get a better interpretation of patterns of entities of the territory framework (associations, relations, connections or hierarchies). 


\section{CONCLUSION}

Geography skills have different levels for prospective teachers and geographers. Skills geography menyakut thinking skills geography (space, phenomena, location and place, region, environment, coordinate, and humans), skills of analysis geography (scale, distribution, patterns of interaction, interrelation, connectivity, corologi, descriptions, and agglomeration), and application skills geography (mapping/cartography, remote sensing, geographic information systems, surveying and mapping of the area, and Global Position systems (GPS)). All levels of geography think part of the construction for geographer in the study of geography. Grouping by using geography skills taxonomy has a function to distinguish the use of knowledge and application of the science of geography.

\section{REFERENCES}

Blij, H, J. De and Muller, Peter O.1993.Physical Geography of the Global Environment.New York: John Wiley \& Sons Inc.

Enok, Maryani., \& Syamsudin, Helius. 2009. Development of Social Skills in Learning Geography. Research Journal, UPI, Bandung.

Hagget, Peter.2001.Geography A Global Synthesis.New York: Pearson Education Ltd., Prentice Hall.

Herbert, David T. And Matthews, John A. 2001. Geography A Very Short Introduction.London: Oxford University.

Higgitt, M. 1996.Addressing the new agenda for fieldwork in higher education, Journal of Geography in Higher Education 20, 3, 391-398.

Kemp, J.2008. Lost in Space: On Becoming a spatially Literate, Knowledge uest, the Journal of the American Association of School Librarians. Volume 36. Number 4 April 2008, the American Library Associate.

Kerski, JJ (2008a). The role of GIS in Digital Earth education, International Journal of Digital Earth, 1: 4, 326-346.

Koutsopoulos, CK (2011). Changing Paradigms of Geography. European Journal of Geography, 1,54-75.

Lee, J., Bednarz, R. (2009). Effect of GIS Learning on Spatial Thinking, Journal of Geography in Higher Education, 33: 2, 183-198.

Lee, J., Bednarz, R. (2012). Components of Spatial Thinking: Evidence from a Spatial Thinking Ability Test, Journal of Geography, 111: 1, 15-26.

Levinson, SC 2003. Space in Language and Cognition: Explorations in Cognitive Disversity.New York: Cambridge University Press.

McCall, MK2008.Participatory Mapping and Participatory GIS (PGIS) for CRA, Community DRR and HazardAssessment.ITC Enschede: Netherlands.

Moeleong, Lexy.2013.Metodology Qualitative Research. Bandung: Rosda.

National Research Council .2005.Learning to Think spatially. GIS as a Support System in the K12 Curriculum.Washington DC: National Research Council and the National Academies Press.

Solem, Michael, Cheung, Ivan, and Schlemper, M.Beth.2008.Skills in Profesional Geography: An Assessment of Workforce Needs and Expectations, 356-373, Association of American Geographers. 